\title{
Behavior constrains the dispersal of long-lived spiny lobster larvae
}

\author{
Mark J. Butler IV ${ }^{1, *}$, Claire B. Paris ${ }^{2}$, Jason S. Goldstein ${ }^{3}$, Hirokazu Matsuda ${ }^{4}$, \\ Robert K. Cowen ${ }^{2}$
}

\author{
${ }^{1}$ Old Dominion University, Department of Biological Sciences, Norfolk, Virginia 23529, USA \\ ${ }^{2}$ University of Miami, Rosenstiel School of Marine and Atmospheric Sciences, Miami, Florida 33149, USA \\ ${ }^{3}$ Department of Zoology, University of New Hampshire, Durham, New Hampshire 03820, USA \\ ${ }^{4}$ Mie Prefecture Fisheries Research Institute, Hamajima, Mie, Japan
}

\begin{abstract}
Behavior such as ontogenetic vertical migration (OVM) limits the transport of marine larvae with short pelagic larval durations (PLDs), but its effect on the supposed long-distance dispersal of larvae with long PLDs is unknown. We conducted laboratory tests of ontogenetic change in larval phototaxis and examined size-specific patterns of larval distribution in the plankton to characterize OVM in the Caribbean spiny lobster Panulirus argus during its long (6 mo) PLD. We then used a coupled biophysical model to explore the consequences of OVM and hydrodynamics on larval $P$. argus dispersal in the Caribbean Sea. Larvae reared in the laboratory were positively phototatic for the first 2 mo and then avoided light thereafter, similar that seen in the planktonic distribution of same-sized larvae. Simulations of larval dispersal from 13 spawning sites in the Caribbean Sea predicted that twice as many larvae would recruit to nurseries if they displayed OVM compared with passive dispersers. Larvae with OVM typically settled $<400 \mathrm{~km}$ from where they were spawned, while passive dispersers often settled $>1000 \mathrm{~km}$ away. OVM also produced an asymmetrical bimodal pattern of dispersal dominated by larvae that settled near their origin $(\sim 60 \%)$, but showed a second peak of larvae that dispersed over long distances $(\sim 20 \%)$. Hydrodynamics created subregional differences in the potential for self-recruitment. Our findings suggest that (1) larval behavior constrains the dispersal of even long-lived larvae, particularly in tandem with retentive oceanographic environments, and (2) larval sources of $P$. argus in the Caribbean Sea cannot be estimated from passive transport and surface circulation.
\end{abstract}

KEY WORDS: Larval dispersal - Vertical migration · Phototaxis · Connectivity · Panulirus argus · Spiny lobster Resale or republication not permitted without written consent of the publisher

\section{INTRODUCTION}

The distance marine larvae are physically transported generally increases with larval duration (Largier 2003, Siegel et al. 2003); thus, species with long pelagic larval durations (PLD) can potentially disperse thousands of kilometers unless constrained by hydrodynamic features or by larval behavior such as vertical migration (Paris \& Cowen 2004, Paris et al. 2007, Woodson \& McManus 2007). Vertical migration, usually controlled by changes in light that occur with photoperiod and depth, is common among marine larvae and is manifested both in daily rhythms and with changes in development (reviewed in Forward 1988). Diel vertical migration, whereby zooplankton rise at night to prey-rich waters near the surface and sink to dimly lit depths during the day, has been known for decades (Clarke 1933) and may change with development (i.e. ontogenetic vertical migration [OVM]), which tends to stratify different larval stages by depth (Leis 2006). Ocean currents also frequently differ in direction or speed with depth (Paris et al. 2002). Thus, after many 
weeks or months of larval development, the dispersal of larvae engaged in vertical migration usually differs from those that drift passively in the sea (see Sponaugle et al. 2002, Pineda et al. 2007 for reviews).

Predator avoidance is generally considered the selective force that has driven the evolution of photobehavior and vertical migration in zooplankton (Ohman 1990, DeRobertis et al. 2000). However, diel vertical migration and OVM also enhance the retention of meroplanktonic larvae in coastal zones and increase their probability of recruitment. Evidence for this comes from studies of stage-specific larval biogeography (e.g. Dennis et al. 2001, Sekiguchi \& Inoue 2002), genetic studies (reviewed by Hedgecock et al. 2007 and by Weersing \& Toonen 2009), mark-recapture studies of larvae bearing natural or artificial tags (reviewed by Thorrold et al. 2007), tracking of larval cohorts in situ from hatching to settlement (Paris \& Cowen 2004, Planes et al. 2009) and predictions of larval dispersal from coupled physical-biological models that include diel vertical migration and OVM (reviewed by Werner et al. 2007). Combined, these investigations present a compelling argument that larval behavior increases self-recruitment of coastal species, that is, the return of larvae to the population from which they were spawned. These new findings refute the conventional wisdom that PLD is a good predictor of dispersal and indicate that the population dynamics of many species are probably more 'closed' than previously believed (Shanks et al. 2003). This shift in the larval dispersal paradigm has important ramifications for the conservation and management of marine resources, including fishery management and the design of marine protected areas (reviewed by Fogarty \& Botsford 2007, Jones et al. 2007).

Yet, the evidence for behavioral enhancement of self-recruitment in marine systems is built almost entirely on studies of species with short PLDs, mostly fishes. It is questionable whether OVM would be as effective in promoting self-recruitment for species with long PLDs and thus providing greater potential for dispersal. The range in PLDs in the sea, particularly among invertebrates, is remarkable-from a few hours (e.g. sponges, ascidians), to weeks (e.g. most molluscs), to several months or even years (e.g. decapod crustaceans) (Bradbury \& Snelgrove 2001). Among those taxa at the longest PLD extreme are spiny lobsters (Decapoda; Palinurdiae) whose larval periods are typically 4 to 12 mo with some as long as $24 \mathrm{mo}$ (Phillips et al. 2006). Unfortunately, many of the techniques devised for the study of larval dispersal in other marine species (e.g. fish) are not applicable to invertebrates like spiny lobsters. Lobsters have no calcified internal structures similar to otoliths in fish, so it is not possible to use elemental fingerprinting to examine population connectivity (see Thorrold et al. 2007). Genetic studies of spiny lobster connectivity have also been hampered by high genetic variability and poor subpopulational genetic differentiation (Ovenden et al. 1992, Silberman et al. 1994, Sarver et al. 2000).

Researchers have instead relied on biophysical modeling to examine larval dispersal in spiny lobsters, with studies of Panulirus marginatus in Hawaii (Polovina et al. 1999), P. argus in the Bahamas and the Atlantic Ocean (Lipcius et al. 2001, Stockhausen \& Lipcius 2001, Briones-Fourzan et al. 2008, Rudorff et al. 2009), P. cygnus in Western Australia (Griffin et al. 2001) and Jasus edwardsii in New Zealand (Chiswell \& Booth 2008). However, only one of these models included larval behavior in its formulation (Griffin et al. 2001), and none have examined its importance to dispersal. Chiswell \& Booth (2008) concluded from their modeling of passive dispersal in lobsters that '... understanding larval behaviour is the most critical aspect in determining larval connectivity'.

The subject of our study, the Caribbean spiny lobster Panulirus argus, is the target of one of the most valuable and widespread fisheries in the Caribbean Sea, valued at nearly US\$500 million but considered fully or overexploited (Ehrhardt 2005, FAO 2006, Chavez 2008). Like all spiny lobsters, $P$. argus has a protracted PLD, which has long been suspected to be 5 to 9 mo (Lyons 1980) and recently estimated at 5 to 7 mo based on laboratory rearing of larvae (Goldstein et al. 2008). This is one of the longest PLDs known for a marine organism in the Caribbean Sea. Larval $P$. argus metamorphose into postlarvae near the shelf break (Yeung \& McGowan 1991), and the nonfeeding postlarvae swim and are transported into vegetated, back-reef nursery habitats (Acosta \& Butler 1999) to which they are attracted by coastal chemical cues, particularly red macroalgae (Goldstein \& Butler 2009), which are their preferred settlement habitat (Marx \& Herrnkind 1985, Herrnkind \& Butler 1986, Behringer et al. 2009). Postlarvae metamorphose into juvenile lobsters that remain within back-reef habitats (e.g. hard-bottom areas, seagrass meadows, mangroves) for 1 to 2 yr until they near maturity when they migrate to the coral reef to join adult populations. Adults spawn along the deeper edges of coral reefs; most spawning occurs from March to June, but continuous spawning by a fraction of the population occurs year-round at lower latitudes (Fonseca-Larius \& Briones-Fourzan 1998, Bertelsen \& Matthews 2001).

Our goals in this study were 2 -fold. First, we quantified OVM in larval Caribbean spiny lobsters by examining age-specific photobehavior in laboratory experiments and stage-specific larval depth distribution from plankton sampling. We then used a coupled 3-dimensional (3D) biophysical model to explore the 
effect of OVM on the dispersal of $P$. argus larvae in the Caribbean Sea, comparing also the effect of oceanographic environment (i.e. advective versus dispersive) on dispersal.

\section{MATERIALS AND METHODS}

Vertical migration of larvae: laboratory experiments. Laboratory culture of phyllosoma larvae: Our laboratory experiments exploring ontogenetic changes in spiny lobster larval phototaxis were conducted on larvae reared in the laboratory according to methods described in Goldstein et al. (2008). In brief, recently mated female Panulirus argus that had not yet spawned were collected in the Florida Keys, Florida, USA, and shipped by air to the Fisheries Research Institute in Hamajima, Mie Prefecture, Japan. The lobsters were held in a 3000 l, temperature-controlled $\left(26.5 \pm 0.5^{\circ} \mathrm{C}\right)$, flow-through seawater tank and fed fresh mussel and frozen krill until they spawned and their eggs hatched. Upon hatching, larvae were collected and cultured at 24 to $25^{\circ} \mathrm{C}$ and 33 to $35 \mathrm{psu}$ in 401 acrylic culture tanks equipped with filtered $(0.2 \mu \mathrm{m})$, flow-through (60 to $\left.90 \mathrm{l} \mathrm{h}^{-1}\right)$ seawater under a $12 \mathrm{~h}$ light:12 h dark photoperiod using full-spectrum fluorescent bulbs (daylight intensity, $\sim 5 \mu \mathrm{mol} \mathrm{m} \mathrm{m}^{-2} \mathrm{~s}^{-1}$ ). Chloramphenicol, an antibiotic, was added to the culture tank weekly. Newly hatched larvae were fed Artemia, whereas older larvae were fed both Artemia and finely minced mussel gonad.

Larval phototaxis experiments: Phototaxis experiments were conducted in 2 cylindrical test chambers made of acrylic (Fig. 1); the smaller chamber (1.1 l, $50 \mathrm{~cm}$ height $\times 6.0 \mathrm{~cm}$ internal diameter [i.d.]) was used in trials with early stage larvae, whereas larvae $>100 \mathrm{~d}$ old were tested in the large chamber $(3.81,50 \mathrm{~cm}$ height $\times 11.5 \mathrm{~cm}$ i.d.). Each chamber was partially immersed in a thermostatically regulated 251 water bath at 24 to $25^{\circ} \mathrm{C}$. The side of each chamber was demarcated into $1 \mathrm{~cm}$ increments for measuring swimming speeds. Light entered the top of the experimental chambers after passing through a filter array (Fig. 1). For our laboratory phototaxis experiments, we used filter arrays that produced wavelengths and light intensities indicative of those observed during the day at 3 depths $(5,50$ and 75 to $100 \mathrm{~m}$ ) in the Caribbean. These depths define the range within which phyllosome larvae are most commonly collected (Bradford et al. 2005). The reference depths and corresponding light spectra and intensities used in our experiments are listed in Table 1. Light characteristics were based on empirical light measurements that we collected with a light meter (model LI-250, LI-COR) during monthly plankton sampling conducted between Miami

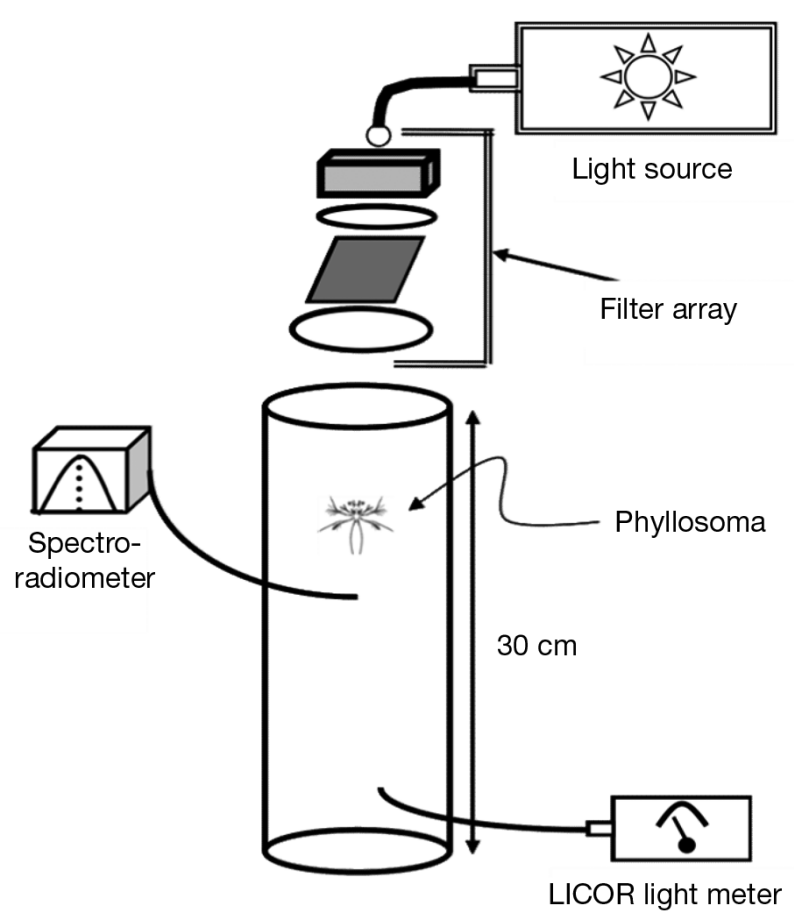

Fig. 1. Panulirus argus. Light chamber apparatus used to test the photoresponse of spiny lobster phyllosome larvae to various light regimes

Table 1. Panulirus argus. Light treatment conditions used in the laboratory phototaxis trials of phyllosome larvae

\begin{tabular}{|lcc|}
\hline Simulated condition & $\begin{array}{c}\text { Wavelength } \\
(\mathrm{nm})\end{array}$ & $\begin{array}{c}\text { Light intensity } \\
\left(\mu \mathrm{mol} \mathrm{m} \mathrm{m}^{-2} \mathrm{~s}^{-1}\right.\end{array}$ \\
\hline Daylight at $0-50 \mathrm{~m}$ depth & $400-600$ & $0.80-1.00$ \\
Daylight at 50-75 m depth & 550 & $0.03-0.04$ \\
Daylight at 75-100 m depth & 470 & $0.03-0.04$ \\
Night with no moonlight & 0 & 0.00 \\
\hline
\end{tabular}

(Florida) and Bimini (The Bahamas) in 2003 and 2004, which were similar to more generalized marine optical reference data (Jerlov 1976). Larvae were also tested in complete darkness to represent nighttime conditions in the absence of reflected lunar light.

The light source for all trials was a $300 \mathrm{~W}$, quartzhalogen, filament lamp (model LGPS, Olympus) projected from a fiber optic cable into a $10 \mathrm{~cm}$ long cylindrical PVC housing that held the light filter array. The filter array consisted of (1) a filter of the desired waveband depending on the light trial, (2) a neutral density filter to achieve equivalent irradiance, (3) a 'hot' mirror with a $45^{\circ}$ to $48^{\circ}$ angle of incidence to reduce heat and bend light appropriately (Snell's Law; Jerlov 1976) and (4) a ground glass diffuser plate to scatter light homo- 
genously. Light filters used in the study were $25 \mathrm{~mm}$ in diameter and constructed of fused silica glass allowing UVA transmittance (Edmund Optics). Spectral composition, output and quality were all tested and verified using a spectrometer (model USB 4000, Ocean Optics). The light intensity was measured with a light meter (model LI-250, LI-COR). Filtered light exited the filter housing and entered the experimental chamber through a $25 \mathrm{~mm}$ hole.

The swimming responses of larvae to the 4 light treatments were tested in the experimental chamber (1 larva per trial) approximately every 2 wk during larval development: 7, 21, 28, 62, 81, 118, 159, 203, 223 and $260 \mathrm{~d}$ after hatch (DAH). We tested 10 to 24 larvae in each of 37 treatments with different combinations of light regime and developmental time; 3 treatments testing larvae <62 DAH at the $550 \mathrm{~nm}$ light level were not conducted due to logistical problems. Trials were run between 11:00 and 16:00 h to minimize potential bias due to endogenous rhythms in photobehavior. Before the start of each trial, individual larvae were removed from group culture, their carapace lengths (CL) measured with a profile projector (model V-12A, Nikon) and then dark-adapted for $45 \mathrm{~min}$ in individual, $400 \mathrm{ml}$, seawater-filled bowls. A single larva was then added in the dark to the center of the light chamber $\sim 20 \mathrm{~cm}$ below the surface and the chamber was then illuminated from the top (Fig. 1). We then measured the vertical distance the larvae moved either toward or away from the light during the 2 min long trial. Larvae were then given a 3 min respite in total darkness before each was exposed to the next randomly chosen light treatment. Thus, each larva was exposed to each of the 4 light treatments (Table 1), similar to the statistical design used in tests of copepod phototaxis by Cohen \& Forward (2002). These data were analyzed using a 2-factor repeated measures ANOVA to test for differences among larval ages (among-subjects factor) and light treatments (withinsubjects factor) for different larvae (subjects) with respect to the distance they moved from the light source. The data did not meet parametric assumptions and various data transformations were ineffective in alleviating the problem, so the data were rank transformed before use in the ANOVA, resulting in a nonparametric analysis (Quinn \& Keough 2002, Zar 2009).

Larval vertical distribution: plankton sampling. Phyllosome larvae were collected during 2003 and 2004 in monthly plankton surveys along a 17 station, $80 \mathrm{~km}$ transect crossing the Straits of Florida at $25^{\circ} 30^{\prime}$ N. Plankton sampling occurred during daylight hours at each station with a combination of neuston and vertically discrete net systems. The neuston net combined a $1 \times 2 \mathrm{~m}$ net (1000 $\mu \mathrm{m}$ mesh) with a $1 \times 0.5 \mathrm{~m}$ net $(150 \mu \mathrm{m}$ mesh). The vertically discrete sampling system was a combined asymmetrical multiple opening-closing net and environmental sampling system (MOCNESS) that supported a $4 \mathrm{~m}^{2}$ net (1000 $\mu \mathrm{m}$ mesh) together with a $1 \mathrm{~m}^{2}$ net (150 $\mu \mathrm{m}$ mesh). Additional technical details concerning the sampling apparatus are presented in Guigand et al. (2005). Nets were opened and closed simultaneously to sample 4 discrete depth ranges: $100-75 \mathrm{~m}, 75-50 \mathrm{~m}, 50-25 \mathrm{~m}$, and 25-0 m. The MOCNESS also was equipped with a flow meter, CTD, fluorometer, transmissometer and downwelled light sensor. Plankton samples were filtered, fixed in $95 \%$ ethanol, filtered again after 3 to $7 \mathrm{~d}$ and then preserved in $70 \%$ ethanol. In the laboratory, the phyllosome larvae were sorted from the $1000 \mu \mathrm{m}$ net samples. Data on fish larvae retrieved from the plankton samples are given in Llopiz \& Cowen (2008). All phyllosome larvae were identified, counted and measured (carapace length [CL]) using either digital calipers or an ocular micrometer.

Modeling larval dispersal. The coupled biophysical larval dispersal modeling system that we used is a spatially explicit individual based model (IBM) composed of 4 stand alone components: (1) a benthic habitat module representing spawning and recruitment habitats, (2) a physical oceanographic module producing 3-D currents, (3) a biological module depicting larval and postlarval life history and behavior and (4) a Lagrangian stochastic model module that tracks the trajectory of individual larvae (particles). The Lagrangian stochastic model integrates, along each individual particle path, information derived from the other modules. Details on the coupled biophysical algorithms and modeling approach can be found in Cowen et al. (2006 with supporting online material) and Paris et al. (2007). Below we describe how the modules were parameterized for Panulirus argus.

The benthic habitat module was coupled to the Lagrangian stochastic model and contained the spawning locations (i.e. larval sources) and coastal habitat information (i.e. presence of suitable nursery areas) accessed by the particle tracking scheme at each time step. The habitat module was a matrix representing both spawning and recruitment areas built using the UNEP-WCMC (Spalding et al. 2001) and Coral Reef Millennium Mapping Project (Andréfouët et al. 2004) remote sensing data. The resulting coverage consisted of 261 discrete habitat polygons of varying size distributed throughout the Caribbean Sea and represented the major spawning and nursery habitats for Panulirus argus. $P$. argus postlarvae settle in vegetated back-reef environments and not on coral reefs per se, but the model's polygons were large enough to represent both reef (spawning habitat) and adjacent nursery habitat. To account for the ability of $P$. argus postlarvae to detect and swim toward coastal settlement habitat (Gold- 
stein \& Butler 2009), a 'postlarval detection buffer' of $18 \mathrm{~km}$ extended offshore of each habitat polygon. This is within estimates of where metamorphosis from the phyllosome to postlarval stage occurs near the shelf edge (Yeung \& McGowan 1991).

The physical oceanographic module consisted of the hybrid coordinate ocean model (HYCOM) global (i.e. $1 / 12^{\circ}$, ca. $7 \mathrm{~km}$ horizontal resolution). HYCOM is a flexible vertical coordinate system: isopycnal in the stratified open ocean, terrain-following in the shallow coastal regions and z-level (depth specific) in mixed layer or unstratified seas. Bottom topography was derived from a quality controlled NRL ETOPOv2 dataset of $2 \mathrm{~min}(3.7 \mathrm{~km})$ resolution. The larval settlement habitat was derived from the Coral Reef Millennium dataset with resolution of $500 \mathrm{~m}$. Coupled to the Lagrangian stochastic model, this module provided daily 3-D current velocities archived from January 2003 to December 2004.

The larval biological module accounted for spiny lobster spawning schedules and early life history traits. Specifically, this module provided information on mortality rate $(M)$, pelagic larval duration (PLD), competency period, ontogenetic vertical migration (OVM) and spatio-temporal patterns in spawning. Since there is no published information on phyllosome larval survivorship, mortality rate was set to a value of $10^{-2} \mathrm{~d}^{-1}$, which is within estimates obtained for fish larvae (Houde 1989). When coupled with variance in individual PLD, this results in differential survivorship among individuals (see Paris et al. 2007). The PLD of lobster larvae in our model was set to a mean value $( \pm 1 \mathrm{SD})$ of $174 \pm 22 \mathrm{~d}$, based on data from laboratory rearing of Panulirus argus from egg to postlarva (Goldstein et al. 2008), which is similar to field estimates based on the time elapsed between peak spawning and peak in the arrival of postlarvae to selected regions (Lewis 1951, Lyons 1980). Larvae in the model metamorphosed to postlarvae within a variable competency period (range, 152 to $196 \mathrm{~d}$ ) and postlarvae were recorded as 'settled' if they came within $18 \mathrm{~km}$ of a benthic nursery habitat polygon within this competency period; if suitable habitat was not encountered within this competency time window they 'died'.

Observed stage-specific vertical distributions of larvae in the field combined with age (size)-specific patterns in larval behavior in the laboratory were used to construct daytime and nighttime age-specific probability density functions (PDF) for each depth bin for larvae in the model. Our goal was to construct behavioral rules that resulted in modeled larval depth distributions that reflected the kind of OVM indicated in field plankton studies (Yeung \& McGowan 1991, Yoshimura et al. 2002), including our own. The resultant age-specific larval depth distributions predicted by the model were then converted to size-specific depth distributions for comparison with observed field data to obtain a good match (see Results). Thus, in the model larvae generally remained in the 0 to $20 \mathrm{~m}$ depth stratum until Day 13, after which they progressively migrated downward in the water column but continued diel vertical migration according to stage-specific PDF, a scenario similar to that described for fish larvae in Paris et al. (2007).

Finally, in the Lagrangian stochastic model, larvae released from the benthic habitat module were moved at each time step $(\Delta t=7200 \mathrm{~s})$ using the 3 -D velocity fields from the oceanographic module by a 4 th-order Runge-Kutta integration of the ordinary differential equation. Turbulence smaller than the resolution of the ocean model was resolved by random displacement (Paris et al. 2002). In addition to advection and diffusion, larvae were moved vertically following the ontogenetic vertical migration prescribed by the biological module and postlarvae settled with suitable settlement habitat based on information derived from the benthic module, allowing us to track the source and destination of each larva.

Two larval behavior scenarios were simulated: (1) passive dispersion of larvae and (2) active dispersion of larvae exhibiting OVM. Larvae were released from 13 coral reef polygons along the Mesoamerican coast (Fig. 2) and tracked until they died or settled within coastal nursery habitat. Two spawning events were modeled: one in summer and one in winter (June 1 and January 1, respectively, of 2004). At each spawning location, larvae were released (500 particles per location) in the surface layer of HYCOM (i.e. 0 to $20 \mathrm{~m}$ ). The areas from which the larvae were released occur in areas where lobsters are abundant, but the magnitude of release for virtual larvae was an abstraction meant only for comparative purposes and does not represent the true magnitude, seasonality or spatial representation of lobster spawning in Mesoamerica.

For each simulation, we computed the total length of the larval trajectories as well as the dispersal kernel functions $k(x, y)$, defined as the probability distribution of settling distance $x$ of a larva dispersed from a location $y$ in a unit of time (Chesson \& Lee 2005), averaged for the 13 locations and 2 spawning events in each of the scenarios. The range and variance of the dispersal kernels serve as a measure of the spatial scale of dispersion. The dispersal kernel (i.e. probability of larval arrival as a function of distance) was estimated by fitting to a polynomial function $f(x)$ and scaled to sum 1. The mean dispersal distance was then computed using the following equation:

$$
\mathrm{DM}=\int_{-\infty}^{\infty} x \cdot f(x) \cdot \mathrm{d} x
$$

where DM is the mean dispersal scale and $f(x)$ is the function fitted to the dispersal kernel. 


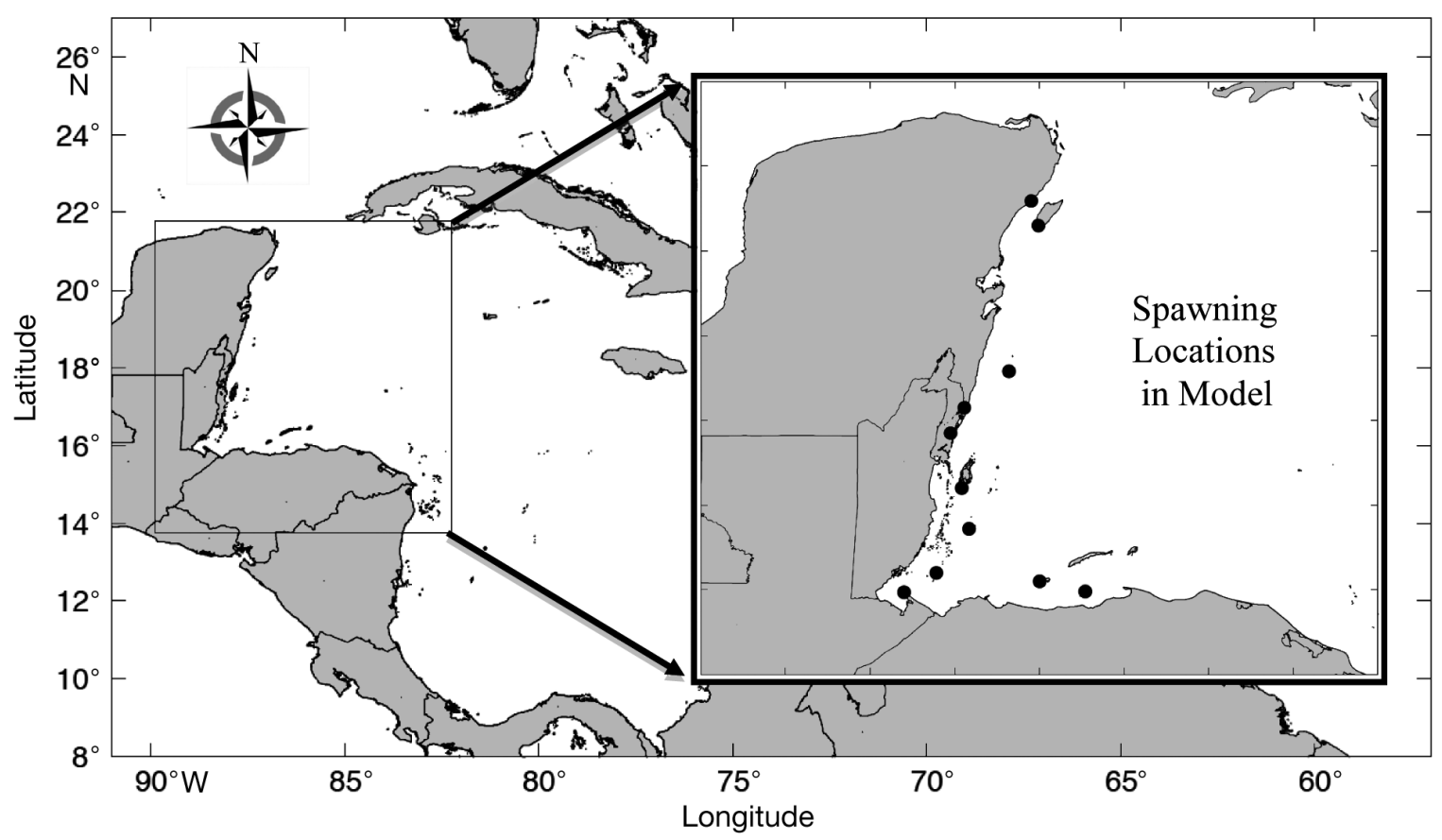

Fig. 2. The Mesoamerican region of the Caribbean Sea showing the locations of the 11 spawning sites (i.e. larval particle release sites; $\bullet$ ) used in the model simulations

\section{RESULTS}

\section{Larval phototaxis experiments}

All of the larvae we tested were active and swam vigorously in response to light. Larval age, light treatment and their interaction all significantly affected the movement of Panulirus argus larvae in the laboratory experiments (Table 2). The significant interaction between larval age and light treatment reflected small differences in age-specific swimming responses rather than more general patterns. Early stage larvae were positively phototactic and moved closer to the light source than did later stage larvae in all 3 light treatments (Fig. 3). A distinct behavioral transition in larval response to light occurred at about $100 \mathrm{~d}$ posthatch, corresponding to a larval size of 10 to $15 \mathrm{~mm} \mathrm{CL}$. At this age, larvae became negatively phototactic and were no longer attracted to light of any wavelength we tested. Larvae displayed little directional movement in the dark and either maintained their position in the water column or sank slowly, the latter behavior being more common among the later larval stages (Fig. 3).

\section{Larval vertical distribution: plankton sampling}

Overall, 6666 Panulirus argus larvae were collected at 390 stations during the $2 \mathrm{yr}$ of monthly plankton sampling. Larvae were generally collected in all months and at all stations and showed considerable variation among cruises in abundance, size and spatial distribution. Seasonal variation was evident in terms of the total number of larvae collected (maximum in July and minimum during February and March) and their

Table 2. Results of 2-factor repeated measures ANOVA on rank-transformed data testing the effects of larval age and light treatment (repeated measure) on the distance that larvae moved away from their starting position. Results of post hoc Tukey's Honestly Significant Difference tests comparing age treatments among larvae and light treatments are presented below the ANOVA table; treatment groups sharing an underline are not significantly different from one another at the $\mathrm{p}<0.05$ level

\begin{tabular}{|c|c|c|c|c|c|}
\hline \multicolumn{2}{|l|}{ Source } & df & MS & $F$ & $\mathrm{p}$ \\
\hline \multicolumn{2}{|l|}{ Larval age } & 9 & 124893.7 & 10.101 & $<0.0005$ \\
\hline \multicolumn{2}{|l|}{ Error } & 85 & 12364.5 & & \\
\hline \multicolumn{2}{|c|}{ Individual larvae (age) } & 84 & 12774.4 & 6.357 & $<0.0005$ \\
\hline \multicolumn{2}{|c|}{ Light treatment } & 3 & 35422.8 & 17.627 & $<0.0005$ \\
\hline \multicolumn{2}{|l|}{$\begin{array}{l}\text { Larval age } \times \\
\quad \text { Light treatment }\end{array}$} & 25 & 4606.2 & 2.292 & $<0.001$ \\
\hline \multicolumn{2}{|l|}{ Error } & 224 & 2009.5 & & \\
\hline \multicolumn{2}{|l|}{ Total } & 345 & & & \\
\hline \multicolumn{6}{|l|}{ Tukey results } \\
\hline Larval age $(\mathrm{d})$ : & $\begin{array}{l}721 \\
\end{array}$ & 128 & $62 \underline{118 \quad 203}$ & $3 \quad \underline{159} 26$ & $\underline{60} \underline{223 \quad 81}$ \\
\hline Light treatment: & $\underline{0-50}$ & $0 \mathrm{~m}$ & $\underline{50-75 \mathrm{~m}}$ & Dark & $75-100 \mathrm{~m}$ \\
\hline
\end{tabular}




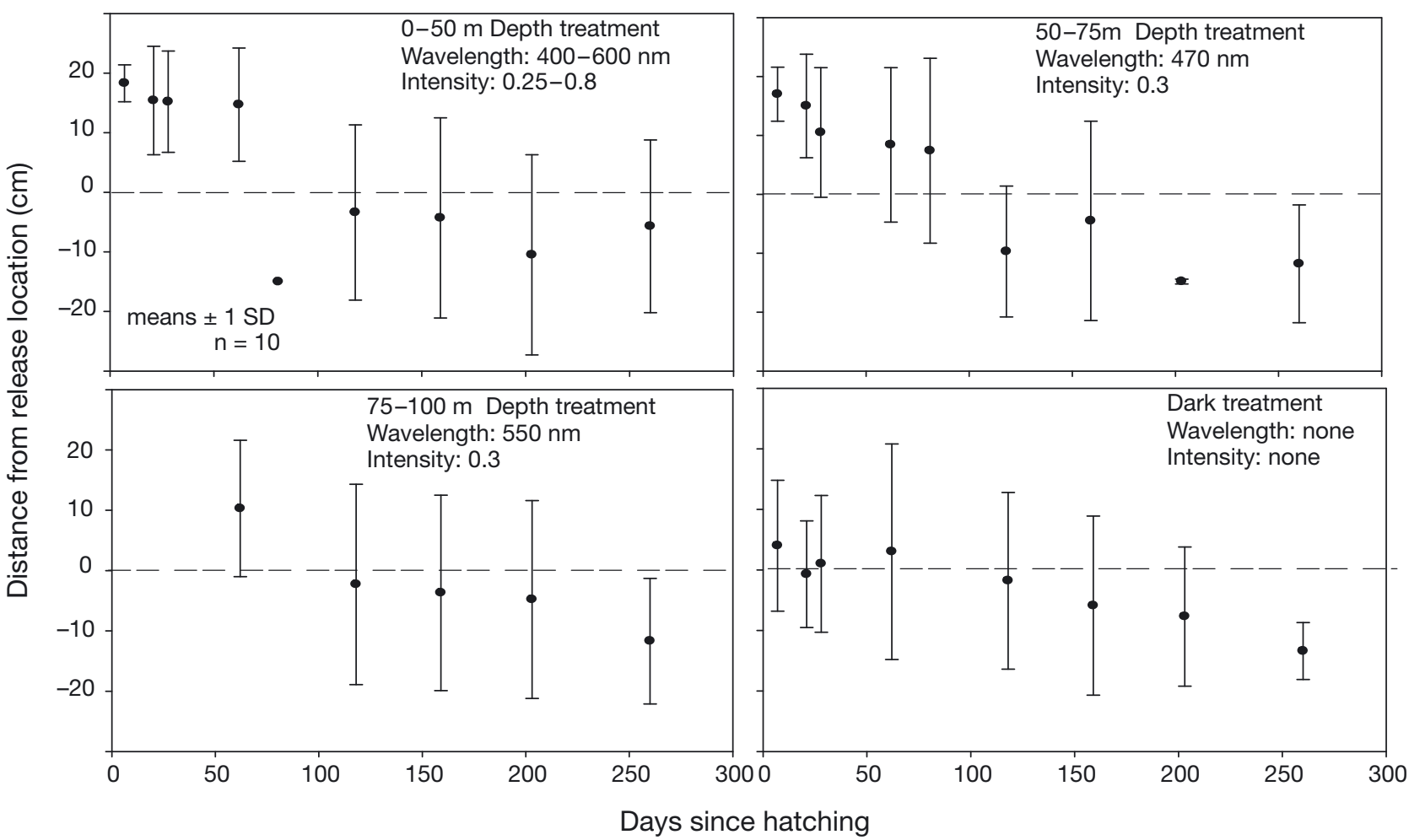

Fig. 3. Panulirus argus. Results of laboratory experiments conducted to examine ontogenetic changes in the phototaxis of larvae. The 4 panels show results for larvae tested with 4 different light regimes representing conditions during the day at 3 depths $(0-50 \mathrm{~m}, 50-75 \mathrm{~m}, 75-100 \mathrm{~m})$ and at night (no light). In each of the 4 panels, the mean ( $\pm 1 \mathrm{SD})$ distance (cm) that larvae moved ( $y$-axis) away from their starting position (indicated by a horizontal line) in response to the light treatment is presented for larvae of different ages ( $x$-axis). Positive numbers indicate distances that larvae moved toward the light source, whereas negative numbers are distances that larvae moved away from the light source

size frequency (more small larvae of $<10 \mathrm{~mm}$ CL were collected in July to September and more large larvae of $>10 \mathrm{~mm}$ CL were collected in September to November). Small larvae were generally more abundant near shore, whereas large larvae were evenly distributed across the central and eastern portions of the sampling transect but were nearly absent from the western edge close to Florida.

The vertical distribution of larvae collected in the plankton varied by size (Fig. 4a). Fewer than $2 \%$ of the larvae of any size were collected within the neuston (upper $1 \mathrm{~m})$. Smaller larvae $(<15 \mathrm{~mm})$ were almost exclusively found in the upper $50 \mathrm{~m}$ and were evenly distributed between the $0-25$ and 25-50 m depth bins; only ca. $5 \%$ of the small larvae were found below $50 \mathrm{~m}$ depth. As larvae increased in size, so did their proportional occurrence in deeper waters. Although never completely absent from the upper layers, the proportion of larvae found deeper than $50 \mathrm{~m}$ increased from ca. 5 to $29 \%$ as larval length increased in all 4 size categories. The change in depth was initiated by larvae within the 5-10 $\mathrm{mm}$ size category and was complete by $15 \mathrm{~mm}$.

\section{Modeling larval dispersal}

Dispersal by passive versus vertically migrating larvae

The resulting pattern of OVM simulated in the model that emerged from our larval behavioral rules (Fig. 4b) was similar to that observed in plankton tows (Fig. 4a). The depth bins used in the model (every $20 \mathrm{~m}$ ) and those sampled in the field (every $25 \mathrm{~m}$ ) were not identical, so there is no way to know for certain how old the field caught larvae of a given size really were. Although the model and field data on OVM defy a truly direct comparison, their similarity is striking. In both graphs one can see that larvae less than $90 \mathrm{~d}$ old were found almost exclusively at depths $<40$ to $50 \mathrm{~m}$, larvae between 90 and $130 \mathrm{~d}$ old were found mostly at 20 to $50 \mathrm{~m}$, and those older than $130 \mathrm{~d}$ were increasingly found at depths of 40 to $60 \mathrm{~m}$ or more. The largest discrepancy between the model and field data was for larvae $<90 \mathrm{~d}$ old in surface waters, but this is probably a reporting artifact. The model data include many larvae that were just a few days old, which in reality would still be on the shelf near the reef where the off- 


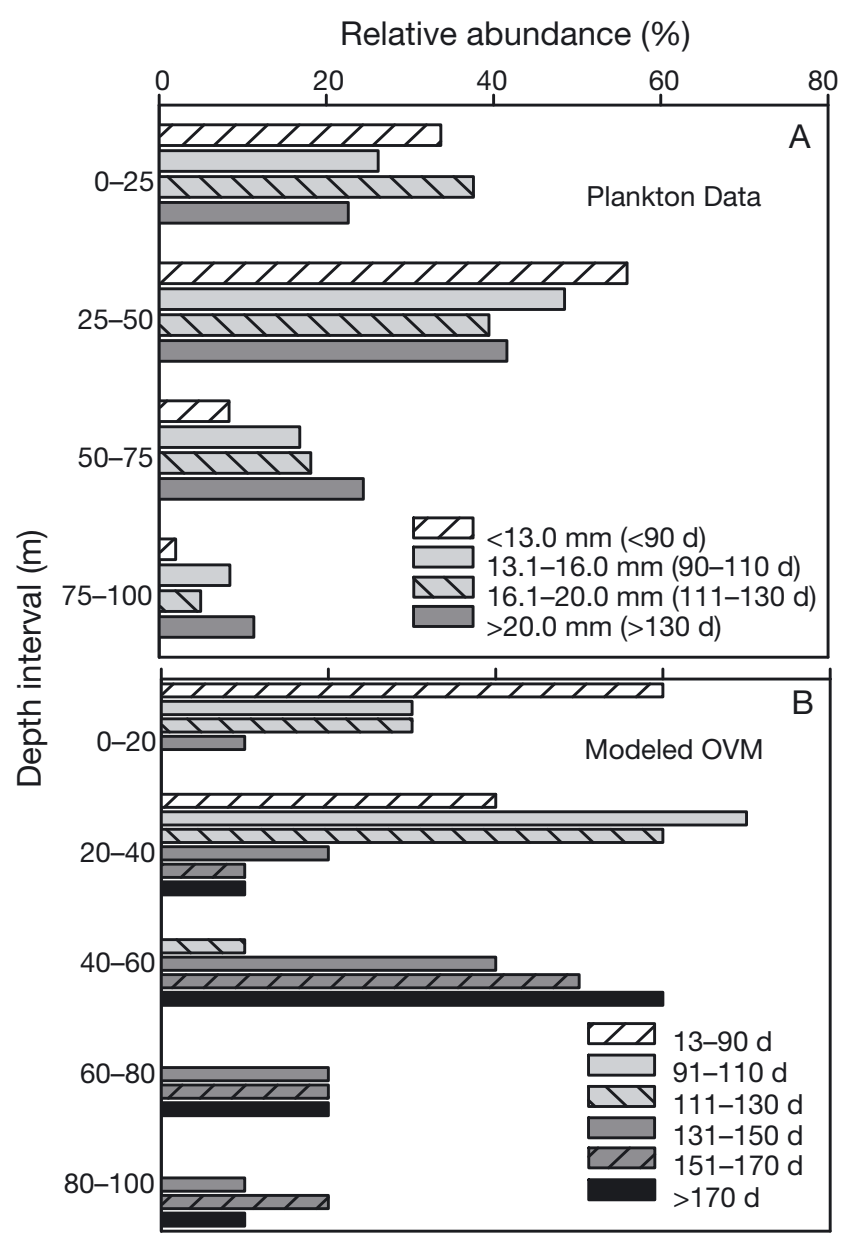

Fig. 4. Panulirus argus. (A) Size-specific depth distribution of phyllosome larvae determined from monthly plankton surveys in 2003 and 2004. The relative abundance of larvae ( $x$-axis) in each of 4 depth bins ( $y$-axis) that were sampled $(0-25 \mathrm{~m}, 25-50 \mathrm{~m}, 50-75 \mathrm{~m}$ and $75-100 \mathrm{~m})$ are plotted for each of the 4 larval size (and estimated age) classes (histograms). (B) Age-specific depth distributions produced by the model algorithm for OVM. Plotted is the relative abundance (\% of total) of larvae ( $x$-axis) in each of 5 modeled depth bins (y-axis) for larvae of different ages (histograms)

shore plankton sampling would have missed them. Thus, we believe that ontogenetic changes in larval vertical migration as simulated in the model provided a good representation of OVM as approximated from field plankton sampling and thus is a valid comparison of the potential effect of vertical migration on dispersal compared with passive dispersers.

Simulations comparing the settlement of passively dispersing larvae to that for larvae exhibiting OVM (Fig. 5) indicated that larval behavior resulted in more than twice as much settlement into nursery habitat polygons than did passive transport. Even after an average of 6 mo in the plankton, during which time larvae traveled 22 to $45 \mathrm{~km} \mathrm{~d}^{-1}$, settlement of larvae with
OVM was most often within $400 \mathrm{~km}$ of their spawning sites (mean $=370 \mathrm{~km}, \mathrm{SD}=110 \mathrm{~km}$; Fig. 5). In contrast, passively dispersing larvae settled nearly $1000 \mathrm{~km}$ $($ mean $=952 \mathrm{~km}, \mathrm{SD}=650 \mathrm{~km})$ from their spawning sites (Fig. 5). The dispersal kernels for both active and passive larvae were bimodal, but the kernel for active larvae was strongly asymmetrical with the peak dispersal being much closer to the origin. Examples of dispersal trajectories are shown in Fig. 6 for 6 of the spawning release sites, including 2 sites in Belize with contrasting offshore oceanographic conditions (Ambergris Cay, Fig. 6C; Glovers Atoll, Fig. 6D), which are discussed in detail below.

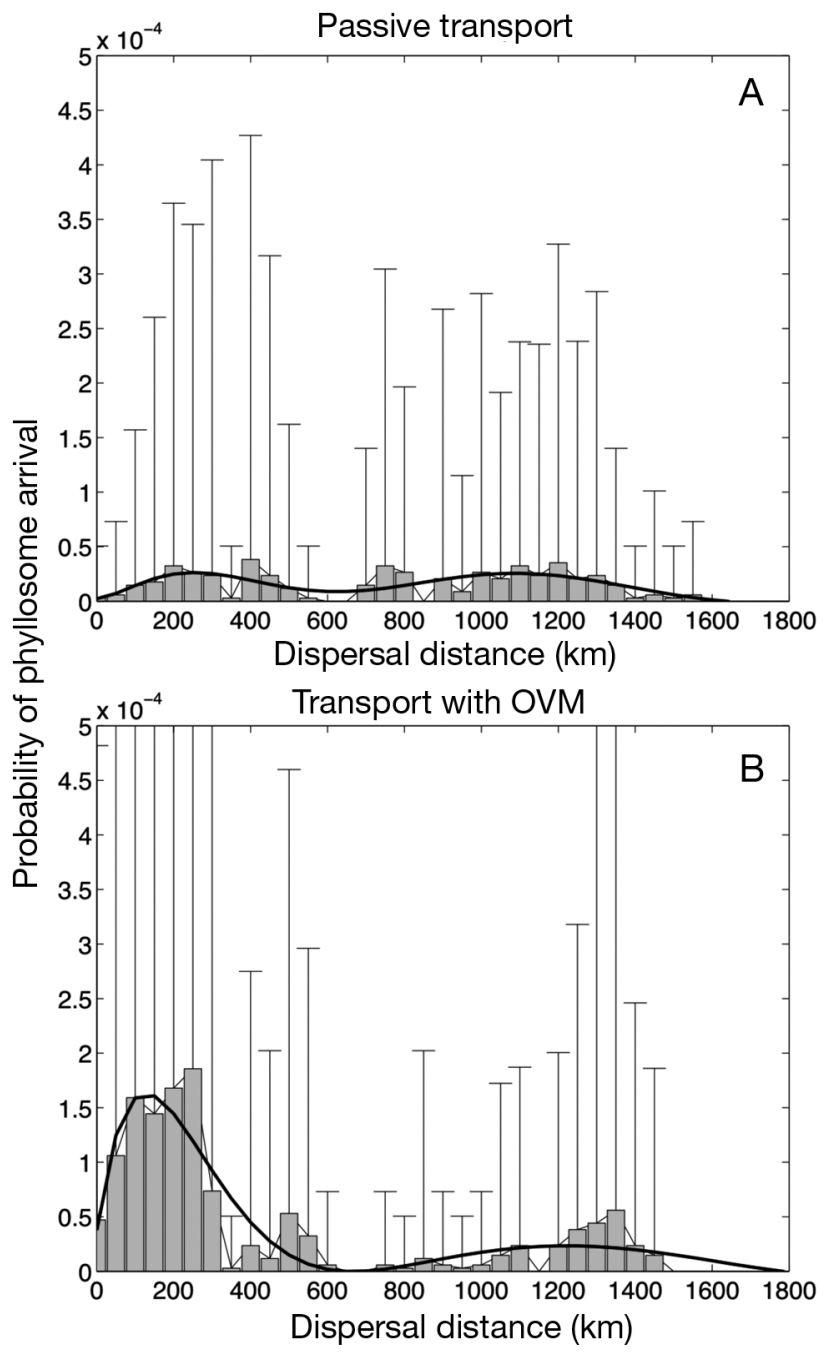

Fig. 5. Panulirus argus. Dispersal kernels (histograms) for spiny lobster phyllosome larvae with and without OVM depicted as the mean probability $\left(\times 10^{-4} \pm 95 \% \mathrm{CI}\right)$ that dispersed and arrived at settlement habitat locations at different distances $(\mathrm{km})$ from 11 spawning sites in the Caribbean Sea. (A) Simulation results for passively transported larvae compared with (B) simulations where larvae engaged in OVM. The smoothed lines are the best-fit lines for the dispersal histograms 
Dispersal in retentive versus advective environments

The results of the simulation comparing passive and active Panulirus argus larval dispersal from 2 spawning sites in Belize, which differed in coastal oceanography, were similar to the results of the overall simulation runs for all of the 13 release sites. Simulations for the 2 contrasting sites in Belize revealed that total settlement increased by a factor of 4 when larvae vertically migrated, and also resulted in settlement occurring appreciably closer to spawning sites (ca. $570 \mathrm{~km}$ closer) than when larvae dispersed passively (Fig. 7). The maximum dispersal of larvae differed little when released in the 2 contrasting environments in Belize. However, the mean dispersal was much lower in the retentive environment near Glovers Atoll (mean dispersal = $210 \mathrm{~km}$ ) than at Ambergris Cay (mean dispersal $=500 \mathrm{~km}$ ) where larvae tend to be swept northward (Fig. 7).

The shape of the dispersal kernels also differed between these contrasting hydrodynamic environments depending on larval behavior (Fig. 7). In the advective environment near Ambergris Cay, dispersal was greater and more evenly distributed between 500 and $1500 \mathrm{~km}$ when larvae drifted passively. The shape of the bimodal dispersal kernel became strongly asymmetrical when larvae engaged in OVM; most larvae settled ca. $250 \mathrm{~km}$ away, although an appreciable number settled $>1000 \mathrm{~km}$ away. At Glovers Atoll, where a persistent gyre occurs offshore, the dispersal kernel was bimodal for both passive and active larvae, but OVM again accentuated that asymmetry by shifting peak settlement closer $(100 \mathrm{~km})$ to their natal origin.

\section{DISCUSSION}

We used laboratory experiments to explore ontogenetic changes in larval phototaxis, plankton sampling to verify sizespecific larval depth distributions and biophysical modeling to explore the consequences of ontogenetic vertical migration (OVM) and hydrodynamics on the dispersal of spiny lobster larvae. This taxon has a long planktonic larval duration (PLD) and is

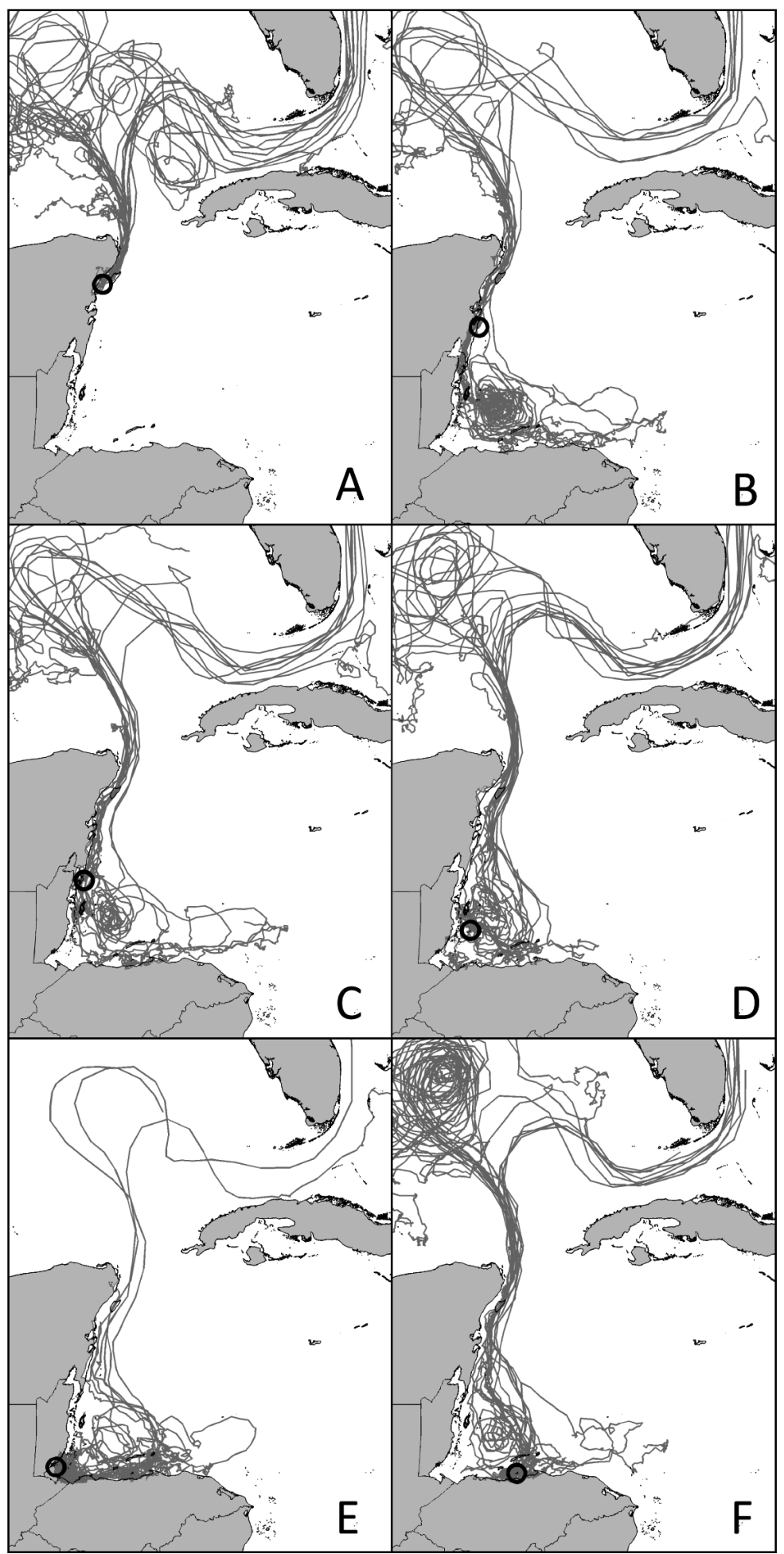

Fig. 6. Panulirus argus. Examples of the effect of local oceanography on spiny lobster larval dispersal from 6 larval release sites $(O)$ in the Mesoamerica region of the Caribbean Sea. Shown are model predictions of the dispersal of larvae (grey lines) exhibiting ontogenetic vertical migration and released from (A) Punta Tupa, Mexico, (B) Mexico Rocks, Mexico, (C) Ambergris Cay, Belize, (D) Glovers Atoll, Belize, (E) Tres Puntas, Guatemala, and (F) Cayos Cochinos, Honduras 


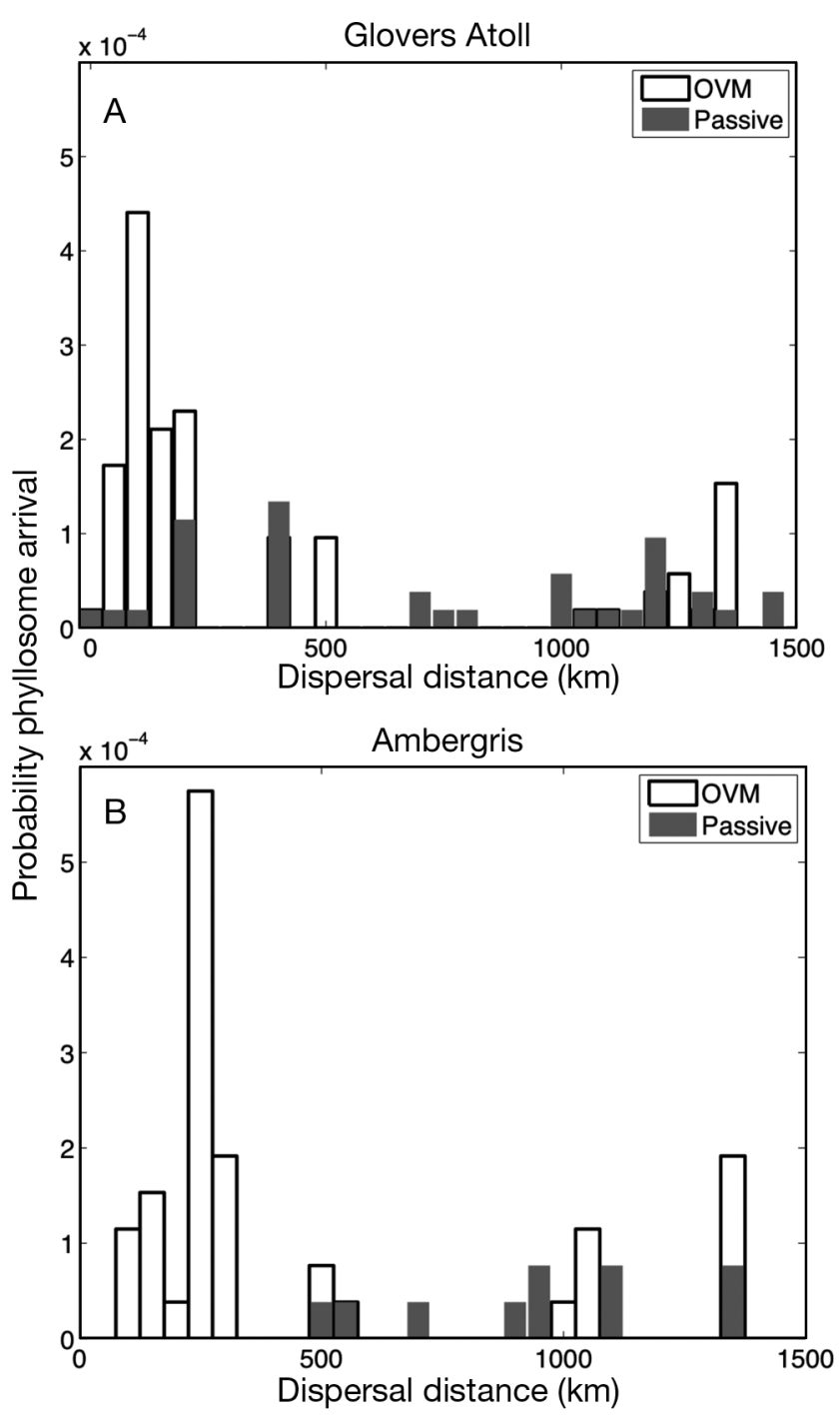

Fig. 7. Panulirus argus. Comparison of the simulated dispersal of spiny lobster larvae exhibiting ontogenetic vertical migration (OVM; open histograms) versus passive larval dispersal (filled histograms) when larvae are released from 2 sites in Belize (A: Glovers Atoll; B: Ambergris Cay) indicative of retentive versus advective oceanographic environments, respectively

assumed to be highly dispersive. Our findings lie in stark contrast to the prevailing ideas about the connectivity of spiny lobster populations in the Caribbean Sea and, more generally, the likely dispersal of species with long PLDs.

The response of laboratory-reared larvae to light regimes similar in intensity and wavelength to those at various depths in the sea changed abruptly after about 3 mo posthatch. The age ( 100 d) and size ( 15 mm CL) of larvae at the time that this change in behavior occurred generally corresponded with the vertical distribution of larvae that we observed during the day in the plankton; smaller larvae $(<15 \mathrm{~mm} \mathrm{CL})$ were found mostly in surface waters $(<25 \mathrm{~m})$ compared with larger larvae (>15 $\mathrm{mm} \mathrm{CL}$ ) that were proportionally more numerous at depths exceeding $75 \mathrm{~m}$. When we incorporated OVM into biophysical simulations we found that it reduced the dispersal of lobster larvae to a fraction of that predicted for passive larvae and more than doubled their predicted settlement in habitable coastal areas. The reduction in dispersal attributable to larval behavior was even evident in regions dominated by strong advective currents, although dispersal from such regions was greater than in regions with persistent coastal eddies. When OVM was invoked, the resultant dispersal kernel for Panulirus argus larvae was asymmetrically bimodal: $\sim 60 \%$ of the larvae settled within $450 \mathrm{~km}$ of their natal site, but a smaller yet notable fraction $(22.4 \%)$ settled $>1000 \mathrm{~km}$ away. Using molecular genetics and parentage analysis of adult and newly recruited juvenile reef fish, Planes et al. (2009) observed a similar phenomenon. In their study, $42 \%$ of the reef fish recruits returned to their natal site after $\sim 30 \mathrm{~d}$ in the plankton, but larvae from the same spawning event also contributed up to $10 \%$ of the new recruits to populations tens of kilometers away.

\section{Larval behavior}

The absence of information on PLD, behavior and mortality of marine larvae has limited advances in biophysical modeling of larval dispersal, as recently noted by Marta-Almeda et al. (2006). Given the logistical constraint that culturing spiny lobsters through their prolonged planktonic phase poses, only 5 of 21 spiny lobster species have been reared through all of their larval stages and fewer still have yielded estimates of PLD or evidence of OVM (Goldstein et al. 2008). In lieu of such information, our understanding of larval behavior in spiny lobsters has come primarily from observations of larval abundance in depth-stratified plankton sampling (see Phillips et al. 2006), as is the case for most marine taxa. By combining size-at-age information derived for laboratory-reared larvae (Goldstein et al. 2008), age-specific changes in larval photobehavior (reported here) and size-specific patterns in larval vertical distribution from our plankton sampling, we estimated age-specific ontogenetic changes in behavior. Our results are consistent with what one would expect with ontogenetic vertical migration, and this information was used in the parameterization of the larval behavior module for our biophysical modeling.

Our laboratory experiments on larval phototaxis were designed to test for ontogenetic patterns in response to light, not diurnal patterns per se. However, our results suggest that early stage larvae $(<100 \mathrm{~d})$ 
probably do not engage in diel vertical migration, whereas late-stage larvae probably do. A positive response to a broad spectrum of light stimuli is characteristic of nonmigratory stages or species that inhabit surface waters where they are exposed to a wide range of wavelengths (Cohen \& Forward 2002). In contrast, species or stages that migrate to the surface at night generally respond to a narrower range of wavelengths and low irradiances indicative of twilight (reviewed in Forward 1988). Our observations that early stage Panulirus argus larvae respond to daylight, but late-stage larvae do not, are thus consistent with the hypothesis of nonmigratory early stage larvae and migratory latestage larvae. Our conclusions regarding diel vertical migration in $P$. argus larvae also agree with observations of larval vertical distribution noted in field studies conducted during the day and night (Buesa 1970, Baisre 1976, Yeung \& McGowan 1991). Diurnal vertical migration by late-stage spiny lobster larvae has also been documented in $P$. japonicus (Yoshimura et al. 2002) and P. cygnus (Phillips \& Pearce 1997), but appears to be absent in Jasus edwardsii (Bradford et al. 2005).

Light may not be the only cue used by decapod larvae for vertical migration. For example, the presence of thermoclines may limit vertical migration, as Austin (1972) surmised from his plankton samples of Panulirus argus larvae for which the lower depth limits he believed were determined by waters cooler than $24^{\circ} \mathrm{C}$. Studies in the Gulf of St. Lawrence show that shrimp respond differently to depth-specific thermal cues depending on larval stage (Ouellet \& Allard 2006). It is clear that the terminal larval stages (e.g. postlarvae) of both crabs and lobsters respond to a suite of signals (e.g. light, chemical, salinity, pressure) that they use for orientation during coastal migration (Forward 1988, Jeffs et al. 2003, 2005, Goldstein \& Butler 2009), and it is conceivable that earlier larval stages may respond to a variety of environmental cues that govern their vertical migration. There currently is no published empirical information available on larval spiny lobster responses to environmental cues other than light; thus, the simulations reported here include only their response to light.

\section{Behavioral effects on dispersal}

Irrespective of the cues that larvae employ to guide them during OVM, modeling results indicated that vertical migration aids in retaining larvae nearer to their spawning site compared with passive dispersal (e.g. Armsworth 2000, Paris \& Cowen 2004, Paris et al. 2007). Together, diel vertical migration and OVM provide a powerful mechanism for bolstering self-recruit- ment of coastal species, especially those with weakly swimming larvae. Diel vertical migration alone is apparently sufficient to counteract the offshore advection of slow-swimming bivalve larvae (Shanks \& Brink 2005) and crab larvae (Marta-Almeida et al. 2006, Incze et al. 2010) in areas dominated by strong upwelling. Similarly, an overwhelming body of evidence now indicates that the presence of OVM in larvae of numerous marine species (reviewed in Almany et al. 2007, Pineda et al. 2007, Planes et al. 2009) aids in retaining or returning those species to coastal nurseries near where they were spawned.

Yet, many biophysical models of larval dispersal still ignore larval behavior and rely on simpler passive particle models that are unlikely to provide a realistic picture of larval dispersal (e.g. Roberts 1997). Until now, all of the oceanographic modeling studies of Panulirus argus dispersal in the Caribbean Sea and south Atlantic Ocean were passive particle models (Stockhausen \& Lipcius 2001, Briones-Fourzan et al. 2008, Rudorff et al. 2009). True ocean circulation and larval dispersal are best resolved with more realistic, coupled biophysical models (reviewed in Werner et al. 2007, Incze et al. 2010). Previous work near Barbados, that used empirical data for the bicolor damselfish Stegastes partitus to validate a model similar to the one we used, has shown that simulations incorporating larval behavior provided a much better fit to real recruitment data than did simulations of passively dispersing fish larvae (Cowen et al. 2003). The only biophysical models of spiny lobster dispersal that include OVM are models developed for $P$. cygnus, a self-recruiting species restricted to Western Australia (Griffin et al. 2001), and the $P$. argus model presented here.

Although our simulation results echo the growing consensus that larval behavior enhances local recruitment (Cowen et al. 2000, 2006, Almany et al. 2007, Cudney-Bueno et al. 2009), we must guard against becoming overly dogmatic in embracing this perspective. The flood of studies demonstrating local recruitment is perhaps overshadowing evidence that distant dispersal can occur at rates that may indeed be demographically relevant and thus large enough to sustain or replenish populations (Becker et al. 2007, Planes et al. 2009). Demographic connectivity can also be extended by rare dispersal events, aided by phenomena such as hurricanes (Briones-Fourzan et al. 2008), that can sustain distant populations, particularly those with long-lived adults (e.g. the storage effect; Warner \& Chesson 1985, Cowen et al. 2006). Our modeling of Panulirus argus larval dispersal suggests that OVM can simultaneously enhance local recruitment and promote distant dispersal, at least for species like $P$. argus with long PLDs. The predicted dispersal kernel for $P$. argus was strongly bimodal with most ( $60 \%)$ larvae 
settling near their origin, but $\sim 20 \%$ settling at distant sites. Average dispersal of $P$. argus in the Caribbean Sea may indeed be only 200 to $400 \mathrm{~km}$ as our simulations suggest. Yet, many simulated larvae were carried $>1000 \mathrm{~km}$ away, enough to create a second mode in the tail of the dispersal kernel and potentially enough to be demographically relevant. Indeed, $P$. argus larvae have been collected in plankton tows throughout the North Atlantic Ocean far from the coast (Sims 1968), and viable populations of $P$. argus occur in Bermuda and the Cape Verde Islands (Freitas \& Castro 2005) thousands of kilometers from potential Caribbean spawning stocks, suggesting that population connectivity at such scales is possible.

\section{Other factors affecting population connectivity}

Larval mortality has a large effect on the probability of demographically relevant connectivity (reviewed in Sponaugle et al. 2002). Our simulations included larval mortality, which was constant across age classes and set at a level similar to that used in simulations of larval fish dispersal (Houde 1989, Cowen et al. 2006). Unfortunately, few empirical estimates of pelagic mortality exist for marine larvae, including decapods. Morgan (1995) suggests that decapod larval mortality generally exceeds $90 \%$. Field experiments with sand dollar larvae, sipunculan larvae and decapod crustacean larvae indicate that mortality of newly settled juveniles may be as high as or higher than that of late-stage planktonic larvae (Acosta \& Butler 1999, Allen \& McAlister 2007). However, estimation of the mortality of early stage planktonic larvae in the open ocean remains elusive. If it is as high as is generally presumed, then variance in pelagic mortality will profoundly affect dispersal kernels and population connectivity, as modeling studies suggest (Cowen et al. 2000, Paris et al. 2007).

Annual, seasonal and short-term fluctuations in oceanographic conditions (e.g. hurricanes) or spawning periodicity can also influence larval dispersal. The greatest fluctuations in settlement of Panulirus argus postlarvae along the Mexican Caribbean coast are correlated with hurricanes and associated sea level changes (Briones-Fourzan et al. 2008), although local winds appear to have little influence on their recruitment (Acosta et al. 1997, Eggleston et al. 1998, Briones-Fourzan et al. 2008). Variance in ocean circulation combined with variability in individual and seasonal reproductive success also creates local and regional patchiness in the connectivity and genetic structure of sea urchin populations in southeastern Australia and New Zealand (Banks et al. 2007). We have not explored the extent to which interannual or seasonal differences in spawning alter the dispersal of the even longer-lived spiny lobster larvae. However, we suspect that the spatio-temporal variation in $P$. argus spawning schedules observed in the Caribbean Sea may result in large differences in the dispersal of these cohorts, as has been demonstrated in simulations of reef fish dispersal under varying seasonal oceanographic conditions (Cowen et al. 2003).

It is also an oversimplification to imply that the supply of spiny lobster postlarvae to the coast predicted by biophysical models necessarily foretells their recruitment. Larval supply is not the only factor controlling recruitment. The availability and suitability of nursery habitat is crucial to the successful recruitment of lobsters (reviewed in Butler et al. 2006) and many other reef species (Steneck et al. 2009). Still, there can be no recruitment without an ample supply of settlers, so understanding larval dispersal and the factors influencing it are critical for understanding population connectivity and its role in sustaining marine populations (Kritzer \& Sale 2006).

\section{Implications for resource management}

The importance of spatial structure and connectivity for the proper management of marine ecosystems is gaining greater recognition (Kritzer \& Sale 2006, Fogarty \& Botsford 2007). Yet, lobster populations in the Caribbean Sea have long been considered to be panmictic, i.e. a single population linked by an intermixing supply of widely dispersing larvae. Support for this hypothesis is based on (1) the long PLD of Panulirus argus and complex ocean circulation in the Caribbean Sea (Lyons 1980), (2) the poor spawning stock to recruit relationship for many local populations of $P$. argus (Butler \& Herrnkind 1997, Lipcius et al. 1997, Cruz et al. 2001) and (3) the various genetic techniques employed over the years that have failed to discern appreciable substructure among $P$. argus populations in the Caribbean Sea (Menzies \& Kerrigan 1979, Silberman et al. 1994, Sarver et al. 1998, 2000). In contrast, management of lobster stocks in the Caribbean region has long been predicated on regulations and stock assessments that assume self-recruitment. Although contradictory to the long-held scientific view of pan-Caribbean lobster populations, this management approach is a pragmatic response given the difficulty of multinational comanagement of stocks and the absence of strong scientific evidence refuting selfrecruitment.

Our results suggest that at the ecological time scales most relevant to management, lobster populations are probably more constrained than scientists previously believed. Nonetheless, local recruitment of 
Panulirus argus within the geopolitical borders by which most fishery management is bounded is unlikely. Even if most dispersal of $P$. argus larvae is only 200 to $400 \mathrm{~km}$ from their spawning sites, as our simulations suggest, that still exceeds the boundaries of most Caribbean nations, especially for stocks distributed near the periphery of those borders. Moreover, the degree to which average dispersal applies to any particular nation varies. Persistent gyres entrain larvae, whereas strong boundary currents sweep them away. So 'local' management of lobster stocks may be more relevant, for example, in places like the Gulf of Honduras (i.e. among Nicaragua, Honduras, Guatemala and Belize) that are strongly influenced by a persistent offshore gyre. In contrast, self-recruitment is unlikely and local management of $P$. argus stocks would be less effective farther north along the Caribbean coast of Mexico where a significant portion of recruiting larvae are probably derived from subsidies originating outside of the region (Briones-Fourzan et al. 2008).

Critical values for demographically relevant recruitment are also not known for most species, including Panulirus argus. Average or mean dispersal distances are generally more likely to be of consequence to demographic connectivity than maximum dispersal, and thus more important in sustaining populations (reviewed by Gaines et al. 2007). However, the bimodal dispersal of $P$. argus suggests there are 2 demographically important components to the recruitment of this species: a strong local element $(<400 \mathrm{~km})$ and a more distant component $(\sim 1000 \mathrm{~km})$. This bimodality in the dispersal kernels results in part from OVM, but is also influenced by regional differences in hydrodynamic conditions and habitat configuration. Cowen et al. (2006) predicted that self-recruitment of reef fish possessing PLDs of $30 \mathrm{~d}$ varied from $9 \%$ in regions with strong boundary currents to a maximum of almost $60 \%$ where semipermanent gyres occur. Our results indicate that local recruitment may be possible even for species with long PLDs, but it is most likely to occur in regions with persistent recirculation features (e.g. southern Cuba, northern Honduras, Panama-Colombia and Dry Tortugas gyres).

In summary, our results underscore the role of larval behavior and regional oceanographic conditions in resolving dispersal kernels and connectivity among populations of coastal marine organisms, even among species with exceptionally long PLDs. As new techniques continue to reveal the true diversity and scales of larval dispersal and those results begin to shift paradigms about population connectivity in the sea, management must evolve in ways that more explicitly consider regional and taxonomic idiosyncrasies in larval retention and advection.
Acknowledgements. Primary funding for this project was provided by the Connectivity Working Group of the Coral Reef Targeted Research (CRTR) Program, a Global Environment Fund-World Bank-University of Queensland international program (www.gefcoral.org). Additional funding was provided by: the National Science Foundation (NSF) International Programs Office; the NSF Geosciences Directorate, Biological Oceanography Program; and by the Ministry of Agriculture, Forestry, and Fisheries of Japan. The authors thank the staff at the Mie Fisheries Institute (Japan) for their assistance (especially T. Takenouchi) and also Tom Healey of the US Fish and Wildlife Service who helped facilitate the transport of specimens. Field and laboratory work for the plankton studies were greatly facilitated by C. Guigand, D. Richardson, J. Llopiz, L. Kamin and R. Howe. Thanks also to A. Srinivasan for algorithm optimization and J. Llopiz for drafting Fig. 4.

\section{LITERATURE CITED}

Acosta CA, Butler MJIV (1999) Adaptive strategies that reduce predation on spiny lobster postlarvae during onshore transport. Limnol Oceanogr 44:494-501

Acosta CA, Matthews TR, Butler MJ IV (1997) Temporal patterns and transport processes in recruitment of spiny lobster, Panulirus argus, postlarvae to south Florida. Mar Biol 129:79-85

Allen JD, McAlister JS (2007) Testing rates of planktonic versus benthic predation in the field. J Exp Mar Biol Ecol 347:77-87

Almany GR, Berumen ML, Thorrold SR, Planes S, Jones GP (2007) Local replenishment of coral reef fish populations in a marine reserve. Science 316:742-744

Andréfouët $\mathrm{S}$, Muller-Karger FE, Robinson JA, Kranenburg CJ, Torres-Pullizza D, Spraggins SA, Murch B (2004) Global assessment of modern coral reef extent and diversity for regional science and management applications: a view from space. In: Proc 10th Int Coral Reef Symp. Japanese Coral Reef Society, Okinawa, p 1732-1745

Armsworth PR (2000) Directed motion in the sea: efficient swimming by reef fish larvae. J Theor Biol 210:1-11

Austin HM (1972) Notes on distribution of phyllosoma of the spiny lobster Panulirus spp. in the Gulf of Mexico. Proc Natl Shellfish Assoc 62:26-30

Baisre JA (1976) Distribucion de las larvas de Panulirus argus y Scyllarus americanus (Crustacea, Decapoda) en aguas alrededor de Cuba. Revista Investigaciones. Cent Investig Pesqueras 2:277-297

Banks SC, Piggott MP, Williamson JE, Bove U, Holbrook NJ, Beheregaray LB (2007) Ocean variability and coastal topography shape genetic structure in a long-dispersing sea urchin. Ecology 88:3055-3064

> Becker BJ, Levin LA, Fodrie FJ, McMillan PA (2007) Complex larval connectivity patterns among marine invertebrate populations. Proc Natl Acad Sci USA 104:3267-3272

Behringer DC, Butler MJ IV, Herrnkind WF, Hunt JH, Acosta CA, Sharp WC (2009) Is seagrass an important nursery habitat for the Caribbean spiny lobster, Panulirus argus, in Florida? NZ J Mar Freshw Res 43:327-337

Bertelsen RD, Mathews TR (2001) Fecundity dynamics of female spiny lobster (Panulirus argus) in a south Florida fishery and Dry Tortugas National Park lobster sanctuary. Mar Freshw Res 52:1559-1565

> Bradbury IR, Snelgrove PVR (2001) Contrasting larval transport in demersal fish and benthic invertebrates: the roles of behaviour and advective processes in determining spatial pattern. Can J Fish Aquat Sci 58:811-823 
Bradford RW, Bruce BD, Chiswell S, Booth JD, Jeffs A, Wotherspoon S (2005) Vertical distribution and diurnal migration patterns of Jasus edwardsii phyllosomas off the east coast of the North Island, New Zealand. N Z J Mar Freshw Res 39:593-604

Briones-Fourzan P, Candela J, Lozano-Alvarez E (2008) Postlarval settlement of the spiny lobster Panulirus argus along the Caribbean coast of Mexico: patterns, influence of physical factors, and possible sources of origin. Limnol Oceanogr 53:970-985

Buesa RJ (1970) Migraciones de la langosta (Panulirus argus). Mar y Pesca 60:22-27

Butler MJ IV, Herrnkind WF (1997) A test of recruitment limitation and the potential or artificial enhancement of spiny lobster populations in Florida. Can J Fish Aquat Sci 54: 452-463

Butler MJ IV, Steneck RS, Herrnkind WF (2006) Juvenile and adult ecology. In: Phillips BF (ed) Lobsters: biology and management. Blackwell Scientific Press, Oxford, p 263-309

Chavez EA (2008) Socio-economic assessment for the management of the Caribbean Spiny Lobster. Proc Gulf Caribb Fish Inst 60:193-196

Chesson P, Lee CT (2005) Families of discrete kernels for modeling dispersal. Theor Popul Biol 67:241-256

> Chiswell SM, Booth JD (2008) Sources and sinks of larval settlement in Jasus edwardsii around New Zealand: Where do larvae come from and where do they go? Mar Ecol Prog Ser 354:201-217

Clarke GL (1933) Diurnal migration of plankton in the Gulf of Maine and its correlation with changes in submarine irradiation. Biol Bull (Woods Hole) 65:402-436

Cohen JH, Forward RB Jr (2002) Spectral sensitivity of vertically migrating marine copepods. Biol Bull (Woods Hole) 203:307-314

Cowen RK, Lwiza KMM, Sponaugle S, Paris C, Olson D (2000) Connectivity of marine populations: open or closed? Science 287:857-859

Cowen RK, Paris CB, Olson DB, Fortuna JL (2003) The role of long distance dispersal in replenishing marine populations. Gulf Caribb Res 14:129-137

Cowen RK, Paris CB, Srinivasan A (2006) Scaling of connectivity in marine populations. Science 311:522-527

> Cruz R, Díaz E, Báez M, Adriano R (2001) Variability in recruitment of multiple life stages of the Caribbean spiny lobster, Panulirus argus, in the Gulf of Batabanó, Cuba. Mar Freshw Res 52:1263-1270

> Cudney-Bueno R, Lavin MF, Marinone SG, Raimondi PT, Shaw WW (2009) Rapid fffects of marine reserves via larval dispersal. PLoS ONE 4:e4140

Dennis DM, Pitcher CR, Skewes TD (2001) Distribution and transport pathways of Panulirus ornatus (Fabricius, 1776) and Panulirus spp. larvae in the Coral Sea, Australia. Mar Freshw Res 52:1175-1185

DeRobertis A, Jaffe JS, Ohman MD (2000) Size-dependent visual predation risk and the timing of vertical migration in zooplankton. Limnol Oceanogr 45:1838-1844

Eggleston DB, Lipcius RN, Marshall LS Jr, Ratchford SG (1998) Spatiotemporal variation in postlarval recruitment of the Caribbean spiny lobster in the central Bahamas: lunar and seasonal periodicity, spatial coherence, and wind forcing. Mar Ecol Prog Ser 174:33-49

Ehrhardt N (2005) Population dynamic characteristics and sustainability mechanisms in key Western Central Atlantic spiny lobster, Panulirus argus, fisheries. Bull Mar Sci 76:501-526

FAO (Food and Agriculture Organization) (2006) Fifth regional workshop on the assessment and management of the Caribbean spiny lobster. FAO Fish Rep 826, Rome

Fogarty MJ, Botsford LW (2007) Population connectivity and spatial management of marine fisheries. Oceanography 20:112-123

Fonseca-Larius ME, Briones-Fourzan P (1998) Fecundity of the spiny lobster Panulirus argus (Latreille, 1804) in the Caribbean coast of Mexico. Bull Mar Sci 63:21-32

Forward RB Jr (1988) Diel vertical migration: zooplankton photobiology and behavior. Oceanogr Mar Biol Annu Rev 26:361-393

Freitas R, Castro M (2005) Occurrence of Panulirus argus (Latreille, 1804) (Decapoda, Palinuridae) in the northwest islands of the Cape Verde archipelago (central-east Atlantic). Crustaceana 78:1191-1201

Gaines SD, Gaylord B, Gerber LR, Hastings A, Kinlan BP (2007) Connecting places: the ecological consequences of dispersal in the sea. Oceanography 20:90-99

Goldstein JS, Butler MJ IV (2009) Behavioral enhancement of onshore transport by postlarval Caribbean spiny lobster (Panulirus argus). Limnol Oceanogr 54:1669-1678

Goldstein JS, Matsuda H, Takenouchi T, Butler MJ IV (2008) The complete development of larval Caribbean spiny lobster Panulirus argus (Latreille, 1804) in culture. J Crustac Biol 28:306-327

Griffin DA, Wilkin JL, Chubb CF, Pearce AF, Caputi N (2001) Ocean currents and the larval phase of Australian western rock lobster, Panulirus cygnus. Mar Freshw Res 52: $1187-1199$

Guigand CM, Cowen RK, Llopiz JK, Richardson D (2005) A coupled asymmetrical multiple opening closing net with environmental sampling system. Mar Technol Soc J 39: 22-24

Hedgecock D, Barber PH, Edmunds S (2007) Genetic approaches to measuring connectivity. Oceanography 20: $70-79$

Herrnkind WF, Butler MJ IV (1986) Factors regulating postlarval settlement and juvenile microhabitat use by spiny lobsters Panulirus argus. Mar Ecol Prog Ser 34:23-30

Houde ED (1989) Comparative growth, mortality, and energetics of marine fish larvae: temperature and implied latitudinal effects. Fish Bull 87:471-495

> Incze L, Xue H, Wolff N, Xu D and others (2010) Connectivity of lobster (Homarus americanus) populations in the coastal Gulf of Maine: part II. Coupled biophysical dynamics. Fish Oceanogr 19:1-20

Jeffs AG, Tolimieri N, Haine O, Montgomery JC (2003) Crabs on cue for the coast: the use of underwater sound for orientation by pelagic crab stages. Mar Freshw Res 54: 841-845

Jeffs AG, Montgomery JC, Tindle CT (2005) How do spiny lobster post-larvae find the coast? Mar Freshw Res 39: 605-617

Jerlov NG (1976) Marine optics. Elsevier Oceanogr Ser Vol 14. Elsevier, Amsterdam

Jones GP, Srinivasan M, Almany GR (2007) Population connectivity and conservation of marine biodiversity. Oceanography 20:100-111

Kritzer JP, Sale PF (2006) Marine metapopulations. Academic Press, New York

Largier JL (2003) Considerations in estimating larval dispersal distances from oceanographic data. Ecol Appl 13: 71-89

> Leis JM (2006) Are larvae of demersal fishes plankton or nekton? Adv Mar Biol 51:57-141

Lewis JB (1951) The phyllosoma larvae of the spiny lobster Panulirus argus. Bull Mar Sci Gulf Caribb 1:89-103

Lipcius RN, Stockhausen WT, Eggleston DB, Marshall LS Jr Hickey B (1997) Hydrodynamic decoupling of recruitment, habitat quality, and adult abundance in the Carib- 
bean spiny lobster: source-sink dynamics? Mar Freshw Res 48:807-816

Lipcius RN, Stockhausen WT, Eggleston DB (2001) Marine reserves for Caribbean spiny lobster: empirical evaluation and theoretical metapopulations recruitment dynamics. Mar Freshw Res 52:1589-1598

Llopiz JK, Cowen RK (2008) Precocious, selective and successful feeding of larval billfishes in the oceanic Straits of Florida. Mar Ecol Prog Ser 358:231-244

Lyons WG (1980) Possible sources of Florida's spiny lobster population. Proc Gulf Caribb Fish Inst 33:253-266

Marta-Almeida M, Dubert J, Peliz A, Queriroga H (2006) Influence of vertical migration pattern on retention of crab larvae in a seasonal upwelling system. Mar Ecol Prog Ser 307:1-19

Marx JM, Herrnkind WF (1985) Factors regulating microhabitat use by young juvenile spiny lobsters, Panulirus argus: food and shelter. J Crustac Biol 5:650-657

Menzies RA, Kerrigan JM (1979) Implications of spiny lobster recruitment patterns in the Caribbean - a biochemical genetic approach. Proc Gulf Caribb Fish Inst 31:164-178

Morgan SG (1995) Life and death in the plankton: larval mortality and adaptation. In: McEdward L (ed) Ecology of marine invertebrate larvae. CRC Press, Boca Raton, FL, p 157-191

Ohman MD (1990) The demographic benefits of diel vertical migration by zooplankton. Ecol Monogr 60:257-281

Ouellet P, Allard JP (2006) Vertical distribution and behaviour of shrimp Pandalus borealis larval stages in thermally stratified water columns: laboratory experiment and field observations. Fish Oceanogr 15:373-389

> Ovenden JR, Brasher DJ, White RWG (1992) Mitochondrial DNA analyses of the red rock lobster Jasus edwardsii supports an apparent absence of population subdivision throughout Australasia. Mar Biol 112:319-326

Paris CB, Cowen RK (2004) Direct evidence of a biophysical retention mechanism for coral reef fish larvae. Limnol Oceanogr 49:1964-1979

Paris CB, Cowen RK, Lwiza KMM, Wang DP, Olson DB (2002) Objective analysis of three-dimensional circulation in the vicinity of Barbados, West Indies: implication for larval transport. Deep-Sea Res 49:1363-1386

Paris CB, Cherubin LM, Cowen RK (2007) Surfing, diving or spinning: effects on population connectivity. Mar Ecol Prog Ser 347:285-300

Phillips BF, Pearce AF (1997) Spiny lobster recruitment off Western Australia. Bull Mar Sci 61:21-41

Phillips BF, Booth JD, Cobb JS, Jeffs AG, McWilliam P (2006) Larval and postlarval ecology. In: Phillips BF (ed) Lobsters: biology, management, aquaculture and fisheries. Blackwell, Oxford, p 231-262

Pineda J, Hare JA, Sponaugle S (2007) Larval transport and dispersal in the coastal ocean and consequences for population connectivity. Oceanography 20:22-39

Planes S, Jones GP, Thorrold SR (2009) Larval dispersal connects fish populations in a network of marine protected areas. Proc Natl Acad Sci USA 106:5693-5697

Polovina JJ, Kleiber P, Kobayashi DR (1999) Application of TOREX-POSEIDON satellite altimetry to simulate transport dynamics of larvae of spiny lobster, Panulirus marginatus, in the northwestern Hawaiian Islands, 19931996. Fish Bull 97:132-143

Quinn G, Keough M (2002) Experimental design and data analysis for biologists. Cambridge University Press, Cambridge

Roberts CM (1997) Connectivity and management of Carib-

Editorial responsibility: Hans Heinrich Janssen,

Oldendorf/Luhe, Germany bean coral reefs. Science 278:1454-1456

Rudorff CAG, Lorenzzetti JA, Gherardi DFM, Lins-Oliveira JE (2009) Modeling spiny lobster larval dispersion in the Tropical Atlantic. Fish Res 96:206-215

Sarver SK, Silberman JD, Walsh PJ (1998) Mitochondrial DNA sequence evidence supporting the recognition of two subspecies or species of the Florida spiny lobster Panulirus argus. J Crustac Biol 18:177-186

Sarver SK, Freshwater DW, Walsh PJ (2000) The occurrence of the provisional Brazilian subspecies of spiny lobster (Panulirus argus westonii) in Florida waters. Fish Bull 98: 870-873

Sekiguchi H, Inoue N (2002) Recent advances in larval recruitment processes of scyllarid and palinurid lobsters in Japanese waters. J Oceanogr 58:747-757

Shanks AL, Brink L (2005) Upwelling, downwelling, and cross-shelf transport of bivalve larvae: test of a hypothesis. Mar Ecol Prog Ser 302:1-12

Shanks AL, Grantham BA, Carr MH (2003) Propagule dispersal distance and the size and spacing of marine reserves. Ecol Appl 13(Suppl):159-169

> Siegel DA, Kinlan BP, Gaylord B, Gaines SD (2003) Lagrangian descriptions of marine larval dispersion. Mar Ecol Prog Ser 260:83-96

Silberman JD, Sarver SK, Walsh PJ (1994) Mitochondrial DNA variation and population structure in the spiny lobster Panulirus argus. Mar Biol 120:601-608

Sims HW (1968) Notes on spiny lobster larvae in the North Atlantic. Q J Fla Acad Sci 29:257-264

Spalding MD, Ravilious C, Green EP (2001) World atlas of coral reefs. University of California Press, Berkeley, CA

Sponaugle S, Cowen RK, Shanks A, Morgan SG and others (2002) Predicting self-recruitment in marine populations: biophysical correlates and mechanisms. Bull Mar Sci 70(Suppl):341-375

Steneck RS, Ablan MC, Alcala A, Arnold S and others (2009) Managing outside the box: coalescing connectivity networks to build resilience in coral reef ecosystems. Coral Reefs 28:367-378

Stockhausen WT, Lipcius RN (2001) Single large or several small marine reserves for the Caribbean spiny lobster? Mar Freshw Res 52:1605-1614

Thorrold SR, Zacherl DC, Levin LA (2007) Population connectivity and larval dispersal. Oceanography 20:80-89

- Warner RR, Chesson PL (1985) Coexistence mediated by recruitment fluctuations: a field guide to the storage effect. Am Nat 125:769-787

Weersing K, Toonen RJ (2009) Population genetics, larval dispersal, and connectivity in marine systems. Mar Ecol Prog Ser 393:1-12

Werner FE, Cowen RK, Paris CB (2007) Coupled biological and physical models: present capabilities and necessary developments for future studies of population connectivity. Oceanography 20:54-69

Woodson CB, McManus MA (2007) Foraging behavior can influence dispersal of marine organisms. Limnol Oceanogr 52:2701-2709

Yeung C, McGowan M (1991) Differences in inshore-offshore and vertical distribution of phyllosoma larvae of Panulirus, Scyllarus, and Scyllarides in the Florida Keys in May-June 1989. Bull Mar Sci 49:699-714

Yoshimura T, Morinaga K, Shirai S, Yamakawa H (2002) Palinurid phyllosoma larvae and their distribution in winter off the Pacific coast of Japan. Fish Sci 68:194-197

Zar JH (2009) Biostatistical analysis. Prentice Hall, Princeton, NJ

Submitted: June 29, 2010; Accepted: October 15, 2010

Proofs received from author(s): January 17, 2011 